THE JOURNAL OF TEACHING ENGLISH FOR SPECIFIC AND ACADEMIC PURPOSES

Vol. 9, No 4, Special Issue, 2021, pp. 675-692

UDC: 811.111 '255 https://doi.org/10.22190/JTESAP2104675M

Original scientific paper

\title{
DEVELOPING A HYBRID DIDACTIC COURSE IN ESP
}

\author{
Nicolas Montalban \\ Universidad Politecnica de Cartagena, Languages Department, Murcia, Spain
}

\begin{abstract}
This paper proposes a hybrid didactic ESP course, which comprises Blended Learning, Flipped Classroom and Project Based Learning with adequate activities. The paper shows that most of the proposed activities stipulate a high fulfilment indicator, and a correlation between a proper selection of didactic materials and the degree of students' achievement and satisfaction at the end of each course.
\end{abstract}

Key words: English for Specific Purposes, Blended learning, Flipped Classroom, Project Based Learning

\section{INTRODUCTION}

This research comes from the intention to improve the current training offer of English language at the National Reference Centre for Chemistry of Cartagena (Spain) and adapt it to new realities and needs. In order to do that, an analysis of the situation of the sub-sectors of Chemistry regarding their training offer in English was implemented. Starting from that, several steps were followed:

- Determination of those sub-sectors in which there are important needs of English language.

- Evaluation of the current training offered and if there is an external and certified evaluation.

- Analysis of the present and future situation concerning demand of the English language in the occupations of Chemical industry.

To determine aforementioned sub-sectors, we analysed all the universe subject to scrutiny. Once we had all companies and associations we prepared a questionnaire which we placed in a web page to be able to collect data from the questions. This questionnaire was posted to mentioned companies. This questionnaire included questions on identifying characteristics of the company, questions on the use of the English language and on training. From gathered data we obtained indexes of dispersion / centrality according to answers, by applying simple statistical criteria, giving rise to statistical indexes such as median, standard deviation and relative standard deviation. From that study we achieved some relevant information concerning on the English language profile of the workers, sub-sectors in which English language was a demanding feature, those linguistic

Submitted March 29 ${ }^{\text {th }}, 2021$, accepted for publication May $10^{\text {th }}, 2021$

Corresponding author: Nicolas Montalban Martinez. Universidad Politecnica de Cartagena, Languages Department,

Murcia, Spain. E-mail: nicolas.montalban@cud.upct.es

(C) 2021 by University of Niš, Serbia | Creative Commons License: CC BY-NC-ND 
competences requested by the jobs and significant areas of usage, quality of the training offer, and obviously some keys to improve training on the English language.

Then, a hybrid approach in the teaching-learning process was prepared, including a complete revision of the offer of ESP courses at the National Centre resulting in this proposal, which was tested in the implementation of five courses.

\section{LITERATURE REVIEW}

Blended learning is a pedagogical hybrid approach defined by a series of varied processes. Graham (2013) defines blended learning as face-to-face teaching (or synchronous) with online teaching being (asynchronous). Research developed on this has reinforced the idea of students' improvement (Dziuban and Moskal 2011; Dziuban, Hartman, Cavanagh, and Moskal, 2011; Means, Toyama, Murphy, and Baki, 2013). It is important to stress that there have been five meta-analysis studies in the last decade on the impact of blended learning related to its efficiency (Zhao, Yan, Lai, \& Tan, 2005; Sitzmann, Kraiger, Stewart, and Wisher, 2006; Bernard, Abrami, Borokhovski, Wade, Tamim, Surkes, and Bethel 2009; Means, Toyama, Murphy, Kaia, and Jones 2010; Bernard, Borokhovski, Schmid, Tamim, and Abrami 2014), having results favouring the introduction of blended learning in contrast to face-to-face teaching.

Margulieux, McCracken and Catrambone (2016) define blended learning courses using the following categories:

- Location: the specific place in which it is developed.

- Distribution media.

- Learning system: traditional, active, etc.

- Synchrony: simultaneous activities developed at the same time.

The implementation of teaching using this methodological approach boosts the selfregulated learning process, following Whiteside, Dikkers and Lewis' (2016) considerations. The introduction of this type of learning methodology gives rise to the usage of new elements and technological tools (Sife, Lwoga and Sanga, 2007). In this didactic intervention, the following have been introduced:

- A system of learning management.

- Tools of virtual communication, such as electronic mails and forums.

- Documents and manuals to be downloaded.

- Flipped classroom.

- Project based learning.

In this hybrid experience, the flipped classroom has been introduced. Olaizola (2014, p.1) states that «the flipped classroom is a specific way of blended learning, a model integrating face-to-face and on-line learning». Walvoord and Johnson Anderson (1998), proposed a model of a flipped classroom in which students, before going to class, have a first approach with contents, and it is in the classroom where the comprehension of the content is achieved (synthesize, analyze and resolve problems). Lage, Platt and Treglia (2000) applied a methodology of flipped classroom to a university course on economy. These authors prepared some didactic materials to be worked on before going to class. Time in class was devoted to explaining activities, debates and discussions in which economic principles were analysed and applied. Crouch and Mazur (2001) proposed a methodology in which the materials are worked on by students before actually going to 
class, and class is devoted to mini-lessons and conceptual questions on the materials. Bergmann and Sams (2012), together with Fornons and Palau (2016) also applied the flipped classroom, achieving an evident improvement regarding students' participation as well as their attitude, favouring a positive working atmosphere. Marlow (2012) implemented a didactic experience with university students, noticing an important decrease in the students' stress levels. On the other hand, Flumerfelt and Green (2013) applied this technique to secondary students with learning difficulties, resulting in an increase of online participatory processes out of the classroom. Roach (2014) and Elliott (2014) obtained positive results when applying this methodology, observing a rise in activities outside the classroom. It is also important to stress O'Flaherty and Phillips' work (2015) exposing multiple synchronous and asynchronous activities. The results of this experience demonstrated the great motivation developed by students, as well as an increase in students' learning efficiency. Cieliebak and Frei (2016) and also Jonsson (2015), evaluated non-technical competences in Engineering students using a flipped classroom, observing better results compared to those obtained using traditional methods. Perdomo (2016) stated that the application of the flipped classroom develops assertive communication, significant learning and students' motivation.

PBL is one of the resources mentioned for blended learning. In this model, students plan, implement and assess projects applied to different environments beyond the classroom (Blank, 1997, Dickinson, et al, 1998, Harwell, 1997). Currently, we are attending to the development of teaching methodologies focused in students' learning and showing a greater involvement of the students in the teaching and learning process (Vega et al., 2014). With this we are introducing active methodologies and, among them, PBL. In this methodology, students play the main role in the educational process; the teacher being a mediator (Vizcarro et al., 2008). It is worth mentioning that this method has been widely used in university teachers' training (Benítez et al, 2013). PBL encourages students to learn, as well as working in a collaborative way in groups searching for solutions to a problem posed by teachers. It is also an extraordinary help in the acquisition of self-paced learning (Saverv, 2006) with students being able to learn autonomously and reaching far better results (Thomas et al., 1999). PBL can be a key tool to develop some competencies, such as working in a collaborative way, using social networks, motivation, creating and problem solving. Students working in PBL environments are able to express a major problemsolving capacity (Finkelstein et al., 2010).

In accordance with the present experiment on the use of Blended learning in ESP courses, including flipped classroom and PBL, bearing in mind the previous research on the sub-sectors in which a training need in English language is needed, the following research question is formulated: can this hybrid approach improve the students' results in terms of the European Framework of Reference for Languages?

\section{MethodOLOGY}

\subsection{Analysis of the current situation of the sub-sectors in which training in English language is needed}

The methodology used to carry out this analysis was a descriptive analysis with a qualitative approach. To have precise knowledge of the situation (Montalbán, 2019), a questionnaire was created on a web page, with the aim of collecting data. This questionnaire was posted to companies and associations belonging to FEIQUE (Federación Empresarial de 
la Industria Química Española), in September 2012. In accordance with its web page, FEIQUE represents the majority of the chemical sector, «a strategic sector for the Spanish economy, comprising 3,300 companies, with an annual invoicing of 65,647 million Euros, generating $13.4 \%$ of the Gross National Income, and 670,000 jobs in Spain. The chemical sector is the second major exporter of the Spanish economy, and the first industrial investor of $\mathrm{R}+\mathrm{D}$ and environmental protection». In addition, the aforementioned questionnaire was also posted to companies, business partnerships and technological institutes, not belonging to FEIQUE.

An analysis of the questions on training states that only $12 \%$ of the companies have a specific offer on English language training and 58\% of those companies consider the implementation of training courses on English language to be urgent, as the training offer of $32.56 \%$ is insufficient. It is worth mentioning that almost $100 \%$ of the answers express the conviction that the labour horizon in the chemical sector is directly dependent on the knowledge of the English language. Regarding the external certification of the English language, the vast majority of companies rely on the Official School of Languages. Nevertheless, Cambridge ESOL Examinations and Trinity College London are also used. We could also infer from the study the following results:

- The main workers who need the English language belong to the following departments: Purchase, Sale, Administration and R+D, representing 41\%. Analysis and Control is 36\%, and Production and Training 23\% (Fig. 1).

- The subsectors of Pharma chemistry and Basic Chemical Products are the most demanding concerning the English language.

- The average needed level is «independent» with $50 \%$, representing the «basic» and «proficient» $25 \%$ each one (Fig. 2).

- The quantity of business in English language is 85-95\%.

- From all answers, only $4.5 \%$ have an external accreditation (Fig. 3).

- Writing business documents in English (Report, Invoices, Budgets, emails, etc., are $33 \%$ (Fig. 4).

- Speaking English in personal interviews and phone contacts is $50 \%$.

- $70 \%$ of the companies have a web page in English.

- The following factors should be improved: Communication and oral expression (60\%), Development of specific texts (29\%), Lexis and Grammar knowledge (8\%) and Motivation (3\%) (Fig. 4).

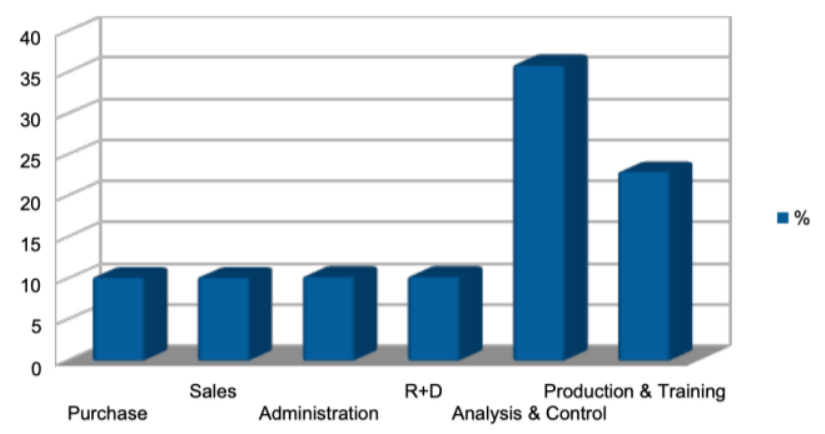

Fig. 1. Distribution of workers using English in departments 


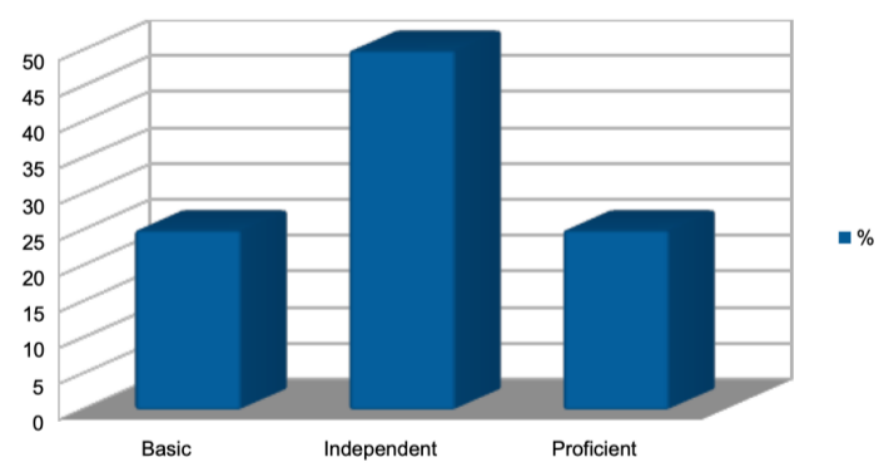

Fig. 2. Most demanded levels of English

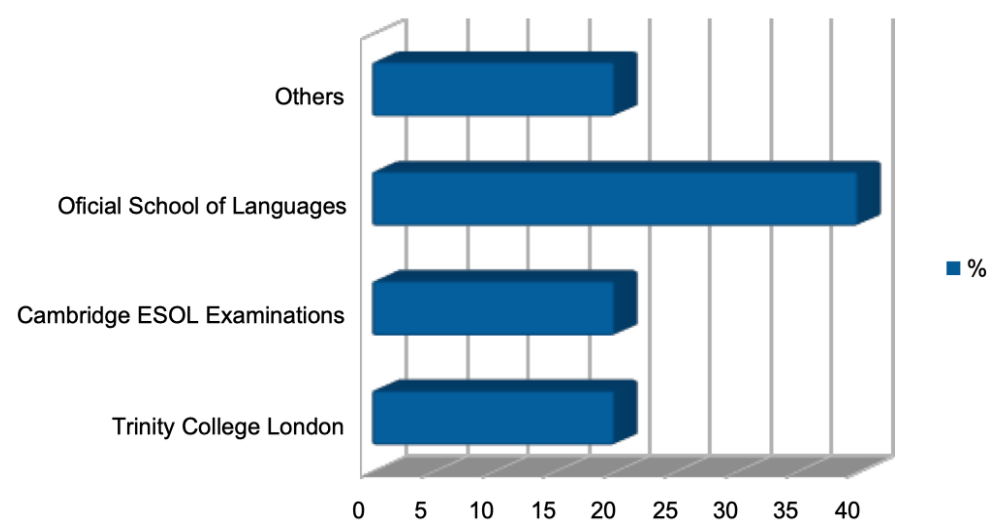

Fig. 3. External certification of the English level

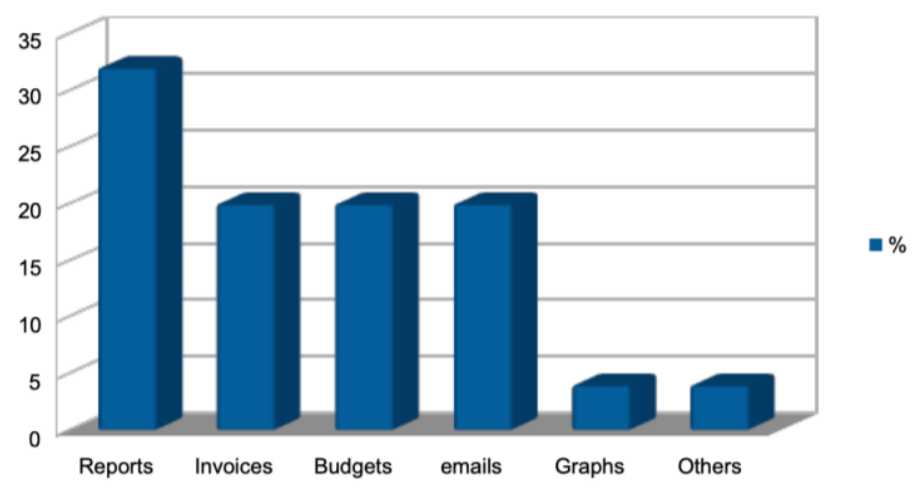

Fig. 4. Documents written in English 


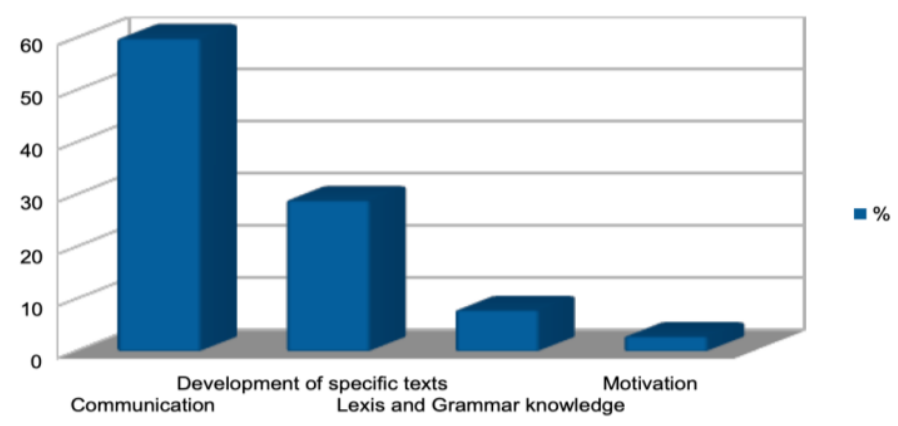

Fig. 5. Factors to be improved

\subsection{Contextualization}

To implement this didactic experience, five two-hundred-hour courses with 15 students in each one were used. These courses were implemented at the National Reference Centre for Chemistry of Cartagena (Murcia, Spain) from 2013-2018 and were on the following subjects:

- English for Quality Control (developed three times)

- Technical English for the Chemical Industry

- Technical English for the Chemical Laboratory

These students were attending a course on non-destructive testing in Spanish at the same time, and some of them hold a university degree in engineering or chemistry. They also took a placement test including the four skills (speaking, writing, listening and reading) at the beginning of the course to know their levels in accordance with the Common European Framework of Reference for Languages. Bearing in mind the importance of interactive teaching and obviously the need to promote that interaction, and that learners' attitudes towards the subject content of the texts should be taken into consideration, the teacher prepared some materials. The contents of this course were decided after discussions with the teachers who developed this course in Spanish, and always bearing in mind the contents previously studied. These contents were as follows:

Table 1. Contents of the course

English for Quality Control CONTENTS

What is NDT?

What is NDE?

Some NDT/NDE Technologies

NDT Certification Levels

Certification Requirements

Certification Examinations

Ten Good Reasons to Consider a Career in NDT Glossary of Terms for PT

What Do NDTers Do?

Where do people in the NDT industry work?

What do people in NDT do?

NDT Certification

Technician versus Engineer

The Science of Nondestructive Testing

Glossary of Terms for MT

Glossary of Terms for UT

Glossary of Terms for RT

Glossary of Terms for ET

Glossary of Terms for VT

General Nondestructive Resource Books and links

What to Study in Preparation for an NDT Career N.D.T. Bilingual Dictionary

NDT Methods 


\subsection{Design and development of the didactic experience}

This project consisted of five stages:

- Initial evaluation to assess students' knowledge of English language using the European Framework of Reference for Languages.

- Implementation of synchronous and asynchronous activities.

- Final evaluation to assess students' knowledge on English language using the European Framework of Reference for Languages and to observe students' improvement.

- External evaluation with Trinity GCSE Examination.

- Final questionnaire on the whole course.

\subsubsection{Initial evaluation}

To properly assess students' initial stage on English language in the four competences, the receptive ones (listening and reading) and the productive (speaking and writing), students took a placement test calibrated between $\mathrm{A} 1$ and $\mathrm{C} 2$.

\subsubsection{Implementation of synchronous and asynchronous activities}

To develop the above courses, a series of sequenced activities orientated to a final project were implemented. Those materials were introduced in the tool MALTED and consisted of:

- Audios.

- Videos.

- Specialized texts.

- Web pages' links.

- Associated exercises to the materials (crosswords, writings with different typologies such as summaries, descriptions, reports, grammar exercises, etc.).

For this work, some didactic materials have been elaborated with the computer tool, Multimedia Authoring for Language Tutors and Educational Development (MALTED Project). This tool, developed specifically for teaching languages, allows students to do practices outside the classroom using TIC's. MALTED is the result of a project by an Educational Multimedia Task Force, supported by the European Union within the framework of Telematics Applications programmes, Socrates and Leonardo da Vinci, within the framework in the learning of languages assisted by computers. It is important to stress that this tool has involved the participation of qualified experts in multimedia programming and education in the U.K, France, Ireland and Spain. In MALTED there are two integrated working environments, the Editor MALTED (DVE) and the Browser MALTED (RTS). The Editor MALTED is really a visual developer for the exercises, as well as work units automatically generated by the XML code. It presents multiple templates that generate exercises for the teaching of languages, as well as text, images, graphs, audio and video, to record the voice by means of an external microphone. In addition, this browsing environment allows students to visualize and complete the exercises and it also offers marks. MALTED received technical support from the Ministry of Education, which managed its maintenance. MALTED provides students with the following advantages:

- It supplies a simple, intuitive and attractive learning environment.

- It does not have a cultural orientation and it is open to multiple didactic approaches.

- It has the necessary flexibility to adapt multimedia materials in different formats.

- It is easy to use. 
In addition, Google sites were created with the following options:

- Documents and assignments, with relevant information for the development of the course (texts and a daily program including tasks with deadlines).

- Videos, podcasts and multimedia, with associated videos and audios.

- References, with links to online dictionaries, related pages, etc.

- Forum, in which permanent discussions were organized around the basic contents of the subject, with questions which triggering students' debates.

It is important to highlight that, to implement this didactic experience, some written didactic resources in English coming from an educational web page (NDT Resource Center) were introduced. To analyze the characteristics of this ESP and take that into account in students' written and oral productions, a tool called Coh-Metrix was used. In accordance with its web page, Coh-Metrix is a tool which produces indexes in linguistic and discourse representations in a text. An important point to comment on is that these indexes are used in different ways to study cohesion of a text and coherence in the mental representation. In the following tables we can see the most important indexes of Coh-Metrix.

Table 2. Indexes of Coh-Metrix

\begin{tabular}{|c|c|c|}
\hline Number & Label & Document \\
\hline 13 & PCNARp & 3,75 \\
15 & PCSYNp & 94,95 \\
17 & PCCNCp & 27,09 \\
19 & PCREFp & 5,26 \\
21 & PCDCp & 52,79 \\
23 & PCVERBp & 1,5 \\
25 & PCCONNp & 3,14 \\
27 & PCTEMPp & 86,86 \\
104 & RDFRE & 32,939 \\
105 & RDFKGL & 10,622 \\
106 & RDL2 & 17,848 \\
\hline
\end{tabular}

In the following table, each index is explained:

Table 3. Explanation on the indexes of Coh-Metrix

\begin{tabular}{|c|c|l|}
\hline Number & Label & Document \\
\hline 13 & PCNARp & $\begin{array}{l}\text { Narrativity expressed in percentage. It advises us on how } \\
\text { familiar words used in English are. }\end{array}$ \\
\hline 15 & PCSYNp & $\begin{array}{l}\text { Syntactic simplicity in percentage. It is saying how small are the } \\
\text { nominal phrases. }\end{array}$ \\
\hline 17 & PCCNCp & $\begin{array}{l}\text { Precision in percentage. It offers the incidence of common } \\
\text { words, to avoid abstract terms. }\end{array}$ \\
\hline 19 & PCREFp & $\begin{array}{l}\text { Referential cohesion in percentage. It says in which way the } \\
\text { same idea is referred in two close sentences. }\end{array}$ \\
\hline 21 & PCDCp & $\begin{array}{l}\text { Deep cohesion in percentage. It expresses the incidence of use } \\
\text { of intentional connective or causal phases. }\end{array}$ \\
\hline 23 & PCVERBp & $\begin{array}{l}\text { Referential cohesion in percentage. It is informing in which way } \\
\text { the same verb is referred to in two close sentences. }\end{array}$ \\
\hline
\end{tabular}




\begin{tabular}{|c|c|l|}
\hline Number & Label & Document \\
\hline 25 & PCCONNp & $\begin{array}{l}\text { Connectivity in percentage. It expresses the incidence of connectors } \\
\text { which communicate sentences in an adversative, additive or } \\
\text { comparative way. }\end{array}$ \\
27 & PCTEMPp & $\begin{array}{l}\text { Temporality in percentage. It informs on the incidence of temporal } \\
\text { connective phrases. } \\
\text { Flesch Reading Ease. Easability of reading in English in } \\
\text { percentage. }\end{array}$ \\
104 & RDFRE \\
106 & $\begin{array}{l}\text { RDFKGL } \\
\text { Flesch kincaid. Technical grade of academic difficulty in English. } \\
\text { Readability for non-native speakers. }\end{array}$ \\
\hline
\end{tabular}

From the analysis of the above Tables 2 and 3, the following conclusions can be reached. The didactic resource has sentences with a high simplicity, a large number of scientific terms of a very high level, which is observed in the low narrativity. Nevertheless, the concepts used do not have a significant concreteness because there are many abstract terms. Moreover, it can be observed that there are not many causal connective sentences, and as there is no reference to concepts (neither nouns nor verbs), it means that it is not characterized by its argumentations. Another feature that should be highlighted is that there is a significant number of temporal connective sentences, in line with texts showing procedures. As referential cohesion of verbs is not stressed over the referential cohesion in general, the didactic materials corresponds with a glossary of terms.

In accordance with the theoretical framework developed before, the characteristics of the ESP to be studied in the didactic materials, the didactic guides of the aforementioned courses (English for Quality Control, Technical English for the Chemical Industry and Technical English for the Chemical Laboratory) were improved and updated. The following series of tasks were developed in all courses:

- Group discussion. Teacher starts interaction by asking students about the importance of NDT, the role played by technicians and engineers in society, and their areas of special expertise and interest in NDT. This task facilitates interaction among all members of the group and content generation.

- The following task is comprehensive reading. Students read a text and learn vocabulary related to NDT.

- After that, students watch a video during which they take notes around the different NDT methods and their importance in industry.

- The next task improves the development of language, allowing students to become familiar with the meaning of specific words, link words with their meanings, use words in sentences and develop a bilingual dictionary (English-Spanish) on NDT.

- Then students prepare a report, organizing ideas with this outline: Aim, Equipment, Procedure and Conclusions. At this stage, students simulate a real situation in which they have to deliver a report to the chemical industry they are working for.

- Now, the class is divided into pairs, starting with an interaction between an NDT technician and a worker, to whom precise instructions should be given on how to proceed when a bridge is damaged. In this situation, vocabulary learned in class is practised. This activity is particularly interesting for students since it is a link with the real world.

- Finally, preparation for Trinity GESE Examination, considered as a final project, triggers interaction among candidates and the examiner. 
Table 4. Series of tasks in all courses

\begin{tabular}{|l|l|}
\hline Tasks & Type of interaction \\
\hline 1) Group Discussion & Group Work \\
2) Reading Comprehension & Individual Work \\
3) Watching - Listening & Individual Work \\
Comprehension & Pair/Group work \\
4) Language Development Activities: & \\
a. Matching words with meanings & \\
b. Using words in sentences & \\
c. Creating a bilingual dictionary on NDT & \\
d. Writing a Report & Pair/Group work \\
5) Roleplay & Individual and Group work \\
6) Final Project: Preparation for & \\
Trinity GESE Examination & \\
\hline
\end{tabular}

\subsubsection{Final evaluation to assess students' knowledge on English language using the European Framework of Reference for Languages and observe students' improvement}

To assess students' level of English, the same placement test was taken a second time.

\subsubsection{External evaluation with Trinity GESE Examination}

Following Trinity College https://www.trinitycollege.com/ web page, «Graded Examinations in Spoken English (GESE) are individual exams, face to face with the examiner, evaluating speaking and listening abilities». This exam comprises the following points:

- Conversation: it is a real opportunity to exchange information.

- Defence of the topic: previous to the exam, candidates prepare a topic to be defended.

- Interactive phase: the examiner starts the interaction with the candidate by making a suggestion.

- Listening: so that the candidate demonstrates predictive, deductive and inference skills.

\subsubsection{Final questionnaire on the whole course}

A Likert or psychometric scale was used at the end of the course with a questionnaire of twenty-three questions by means of Google forms, divided into four sections: conclusions of the analysis of the current situation of English language in the chemical sector and included in the ESP course (questions from 1-17), flipped classroom (questions from 18-20), PBL (questions from 21-22) and external certification (question 23. Students responded from 1 to 5 , where:

- 1 is never.

- 2 is sometimes.

- 3 is often.

- 4 is usually.

- 5 is always. 
Table 5. Final questionnaire

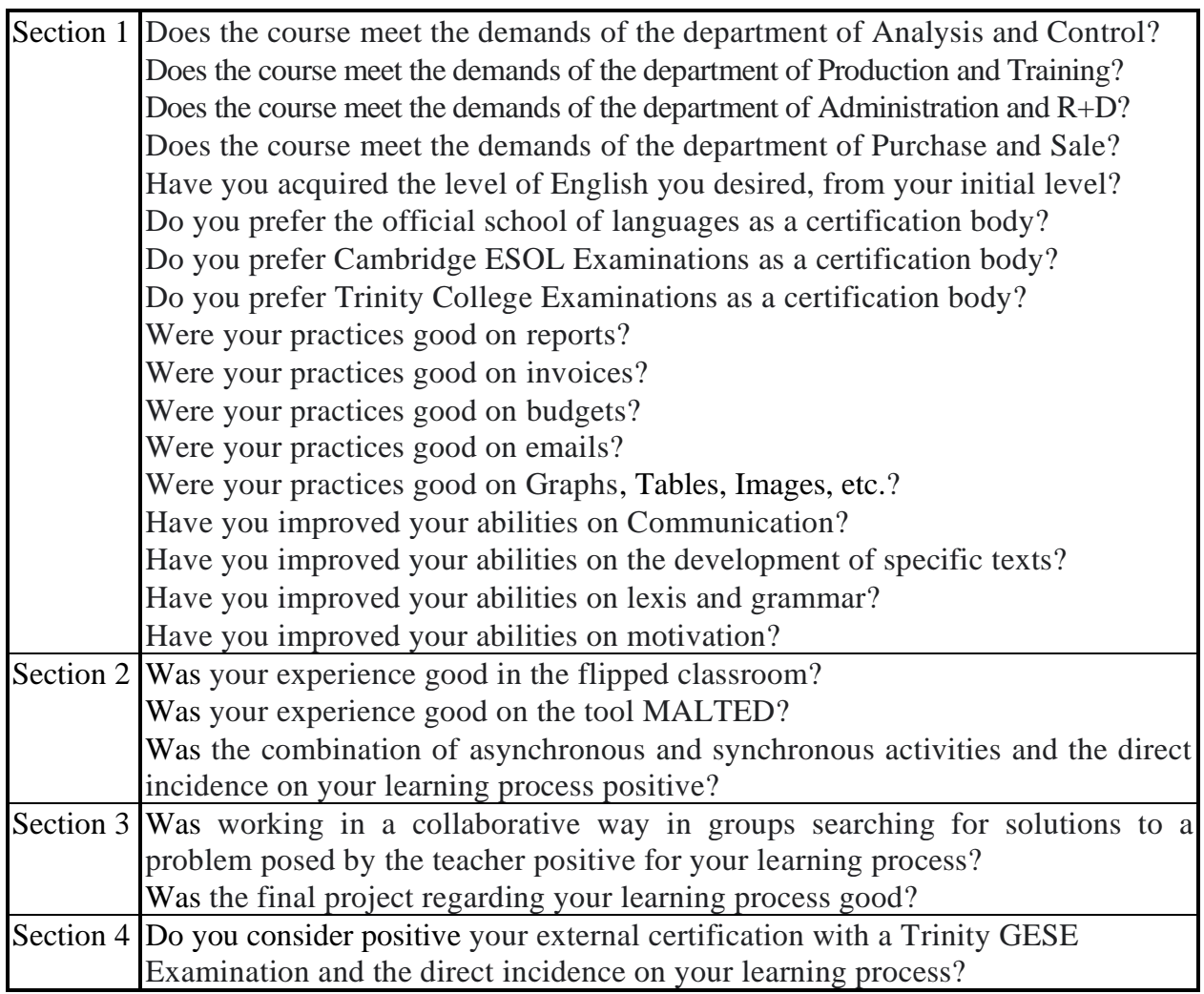

\section{RESULTS}

\subsection{Initial evaluation}

The evaluation starts with a placement test including the four skills (oral examination, listening test, written test and reading comprehension activity), to be able to know students' initial level in accordance with the European Framework of Reference for Languages. The results are as follows:

- A1.1: $73 \%$.

- A2.1: $20 \%$.

- A2.2: $7 \%$. 


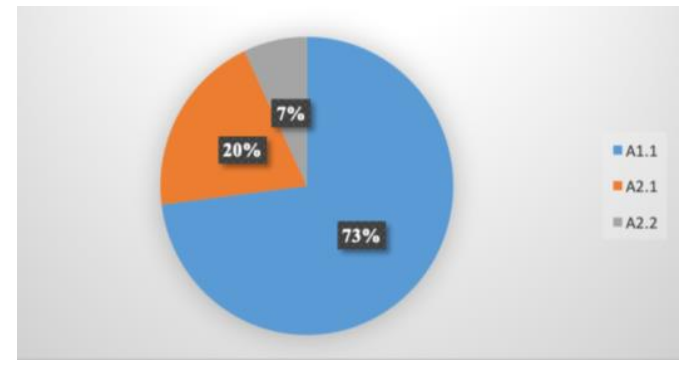

Fig. 6. Results of the placement test

\subsection{Final evaluation}

In this evaluation, students took the same initial evaluation and the results were as follows:

- A2.2: $80 \%$.

- B1.1: $7 \%$

- B2.2: $13 \%$.

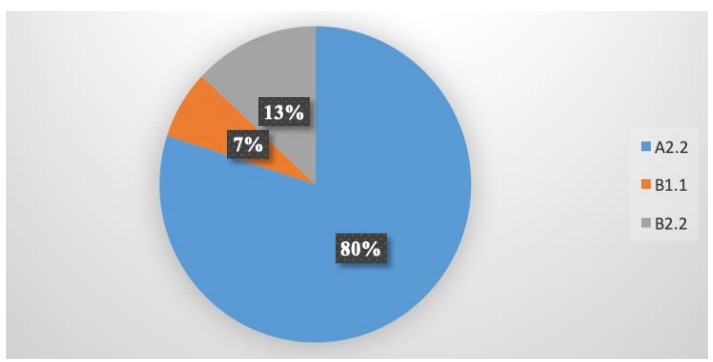

Fig. 7 Results of the final evaluation

\subsection{External evaluation}

With this Trinity examination, students achieved the following results:

- Grades 3/4 (A2): $47 \%$.

- Grades 5/6 (B1): 53\%.

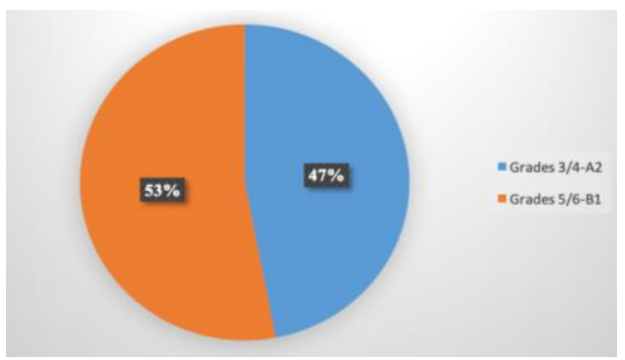

Fig. 8 Results of the external evaluation 


\subsection{Final questionnaire on the whole course}

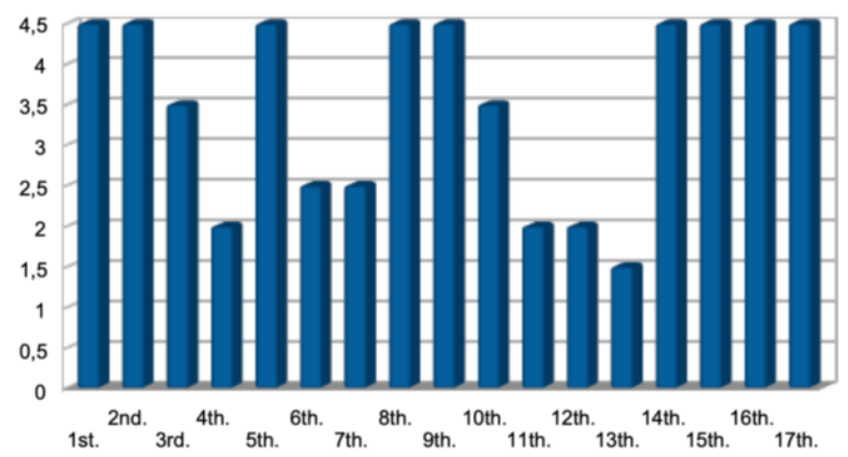

Fig. 9 Questions on the conclusions of the analysis of the current situation of English language in the chemical sector

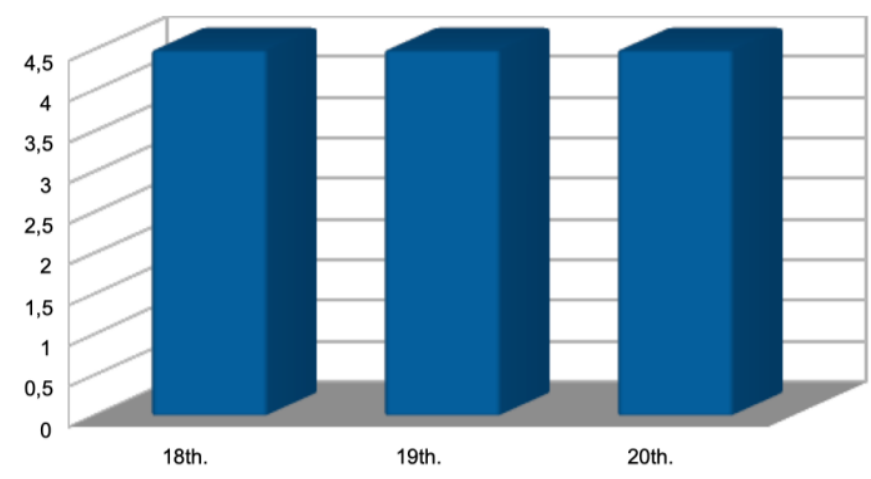

Fig. 10 Questions on the flipped classroom

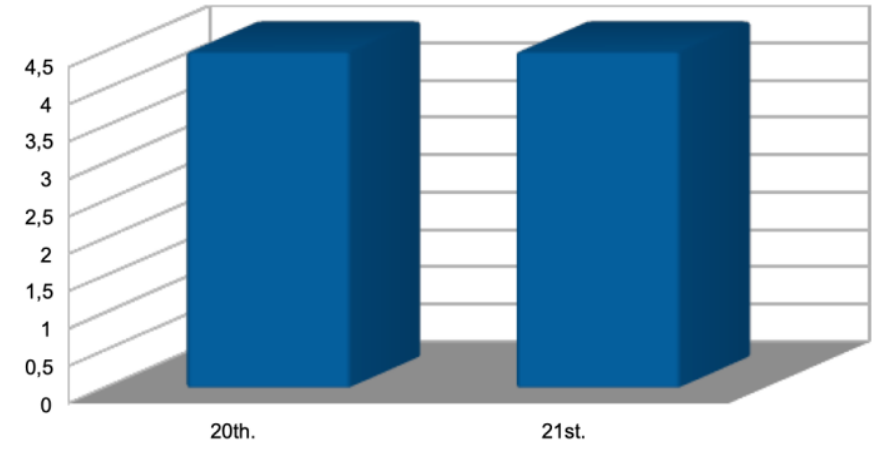

Fig. 11 Question on the PBL 


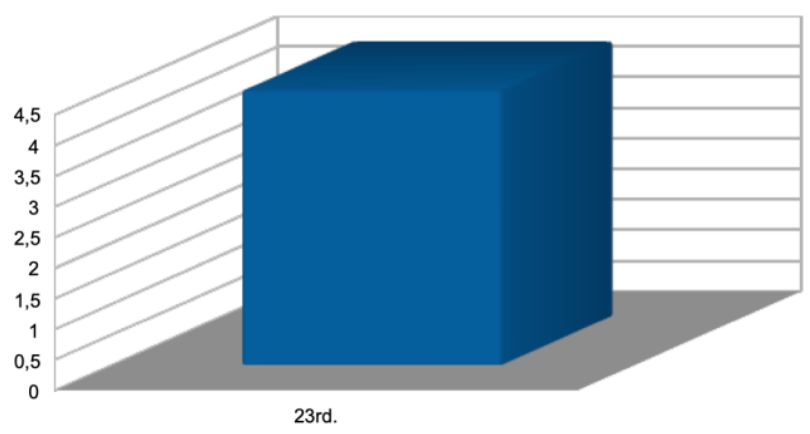

Fig. 12 Question on the external evaluation

\section{DISCUSSION}

From the above results, the following considerations should be highlighted:

There has been a considerable improvement starting from the initial evaluation in which there was a result of A1 73\% and A2 27\%, continuing the final evaluation with A2 $80 \%, \mathrm{~B} 17 \%$ and B2 13\%, and ending with the external evaluation of Trinity GESE Examination (A2 47\% and B1 53\%). Below, there is a Figure explaining this positive evolution in which 1 is the initial evaluation, 2 is the final evaluation and 3 is the external evaluation:

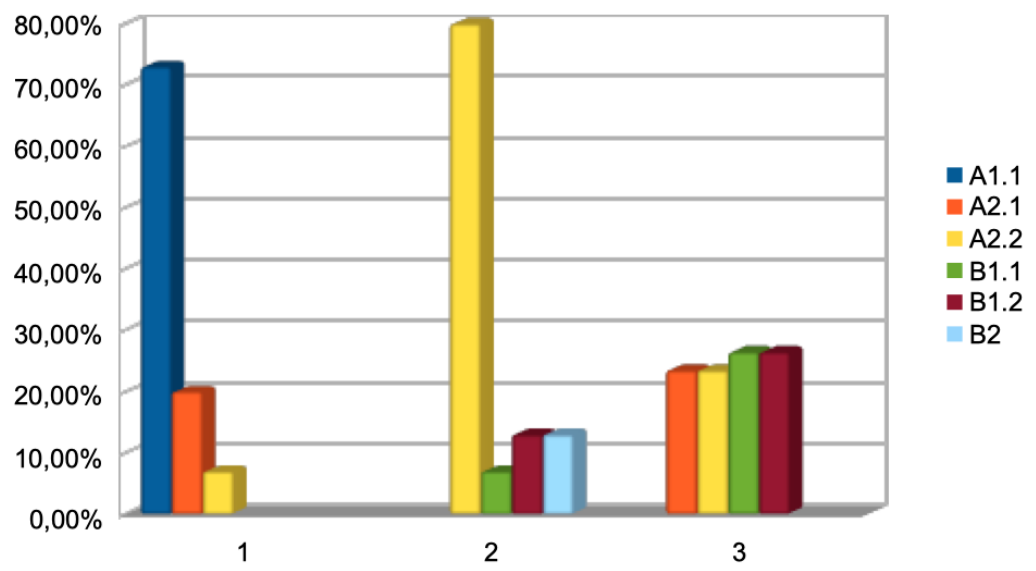

Fig. 13. Students' improvement in the three evaluations

Referring to the final questionnaire based on a Likert scale from 1-5, fifteen questions achieved 4.5, two questions 3.5, two questions 2.5, three questions 2 and 1 question 1.5. 
Consequently, most questions achieved an excellent result, except for questions 13 (1.5), questions 11, 12 and 4 (2) and questions 6 and 7 (2.5). Question 13 referred to practices with graphs, figures, etc. Budgets and emails are other aspects which were probably not dealt with in enough depth. Another aspect which does not have definitive or clear results is that of the certifications bodies preferred by students.

\section{CONCLUSIONS}

Introducing this hybrid proposal combining blended learning, flipped classroom, PBL, as well as the use of MALTED and a selection of materials, has proved to be a positive and enriching one, in accordance with the results discussed above. Moreover, the series of tasks implemented in all courses with the combination of synchronous and asynchronous activities has resulted in more dynamic classes (outside and inside the classroom). The final project is a bridge to the real world by offering students the possibility to apply everything they have learned in a task (GESE Trinity Exam) involving conversation, defence of a topic, interaction and listening.

It is worth mentioning the possibility of introducing blogging, which has resulted in improvements based upon empirical research (Yakut and Aydin, 2017; Sauro and Sundmark, 2018; Fithriani, Rafida and Siahaan, 2019; Montaner-Villalba, 2019) at tertiary level, and Montalbán (2019), who explored blogging in the teaching of ESP, in a learning framework based upon projects (PBL) done with university students, resulting in positive results.

In answer to the research question on whether this hybrid approach improved the students' results in terms of the European Framework of Reference for Languages; from the data obtained, a significant improvement in results can be observed. Therefore, it seems reasonable to conclude that the hybrid approach explained above is worth considering when choosing didactic proposals for ESO courses.

\section{REFERENCES}

Ayşe Didem Yakut and Selami Aydın (2017) An experimental study on the effects of the use of blogs on EFL reading comprehension, Innovation in Language Learning and Teaching, 11:1, 1-16, DOI: 10.1080/17501229.2015.1006634

Bergmann, J., and Sams, A. (2012). Flip Your Classroom: Reach Every Student in Every Class Every Day (pp. 120-190). Washington DC: International Society for Technology in Education.

Bernard, R. M., Abrami, P. C., Borokhovski, E., Wade, C. A., Tamim, R. M., Surkes, M. A., and Bethel, E. C. (2009). A meta-analysis of three types of interaction treatments in distance education. Review of Educational Research, 79(3), 12431289. https://doi.org/10.3102/0034654309333844

Bernard, R.M., Borokhovski, E., Schmid, R.F., Tamim, R.M. and Abrami, P.C. (2014) A Meta-Analysis of Blended Learning: From the General to the Applied. Journal of Computing in Higher Education, 26, 87-122. http://dx.doi.org/10.1007/s12528-0139077-3

Blank, W. (1997). Authentic instruction. Tampa, FL,: University of South Florida. 
Cieliebak, M.; FreI, A. K. (2016): «Influence of flipped classroom on technical skills and non- technical competences of IT students». Paper presented at the Global Engineering Education Conference (EDUCON 2016). IEEExplore Digital Library. http://ieeexplore.ieee.org/document/7474676/

Crouch, C., \& Mazur, E. (2001). Peer Instruction: Ten Years of Experience and Results. American Journal of Physics, 69, 970-977.

Dickinson, K.P., Soukamneuth, S., Yu, H.C., Kimball, M., D’Amico, R., Perry, R., et al. (1998). Providing educational services in the Summer Youth Employment and Training Program (Technical assistance guide). Washington, DC: Department of Labor, Office of Policy \& Research.

Dziuban, C., Graham, C.R., Moskal, P.D. et al. Blended learning: the new normal and emerging technologies. Int J Educ Technol High Educ 15, 3 (2018). https://doi.org/10.1186/s41239-017-0087-5.

Elliott, R. (2014): «Do students like the flipped classroom? An investigation of student reaction to a flipped undergraduate IT course». Paper presented at the Frontiers in Education Conference (FIE 2014). IEEExplore Digital Library.

Finkelstein, M. A. (2010). Individualism/collectivism: Implications for the volunteer process. Social Behavior and Personality: An international journal, 38(4), 445-452.

Fithriani, R., Rafida, T. and Siahaan, A. (2019). Integrating online blogging into EFL writing instruction: Exploring students' perceptions. Paper presented at the 7 th UNNES International Conference on English Language Teaching, Literature and Translation (ELTLT) 2018, Semarang, Indonesia.

Flumerfelt, S.; Green, G. (2013): «Using Lean in the Flipped Classroom for At Risk Students», Educational Technology \& Society, 16 (1), 356-366.

Fornons Jou, V., and Palau Martín, R. F. (2016). Flipped Classroom en la asignatura de matemáticas de $3^{\circ}$ de Educación Secundaria Obligatoria. Edutec. Revista Electrónica De Tecnología Educativa, (55), a322. https://doi.org/10.21556/edutec.2016.55.284

Graham, C. R. (2013). Emerging practice and research in blended learning. In M. G. Moore (Ed.), Handbook of distance education (3rd ed., pp. 333-350). New York, NY: Routledge.

Harwell,S. (1997). Project-based learning, promising practices for connecting high school to the real world. Tampa, FL: University of South Florida.

Jonsson, H. (2015): «Using flipped classroom, peer discussion, and just-in-time teaching to increase learning in a programming course». Paper presented at the Frontiers in Education Conference (FIE 2015). IEEExplore Digital Library.

Margulieux, Lauren; McCracken, W. Michael; and Catrambone, Richard, "A Taxonomy to Define Courses that Mix Face-to-Face and Online Learning" (2016). Learning Sciences Faculty Publications. 2. https://scholarworks.gsu.edu/ltd_facpub/2

Marlowe, C. A. (2012): «The effect of the flipped classroom on student achievement and stress». Master of Science. Bozeman, Master s Thesis: Montana State University.

Maureen J. Lage, Glenn J. Platt and Michael Treglia (2000) Inverting the Classroom: A Gateway to Creating an Inclusive Learning Environment, The Journal of Economic Education, 31:1, 30-43, DOI: 10.1080/00220480009596759

Means, B., Toyama, Y., Murphy, R., and Baki, M. (2013). The effectiveness of online and blended learning: A meta-analysis of the empirical literature. Teachers College Record, 115(3), 1-47. 
Means, B., Toyama, Y., Murphy, R., Bakia, M., and Jones, K. (2010). Evaluation of evidence-based practices in online learning: A meta analysis and review of online learning studies. Washington DC: US Department of Education.

Montalbán Martínez, N. (2019). Estudio sectorial de formación y cualificación en lengua inglesa en la familia profesional de química. Revista De Lenguas Para Fines Específicos, 25(1), 81-106. Retrieved from https://ojsspdc.ulpgc.es/ojs/index.php/ LFE/article/view/822

Montalbán Martínez, N. (2019). La potenciación de la competencia traductológica en alumnos universitarios: una propuesta híbrida. EPOS, Revista de Filología. 35, 181206. DOI: https://doi.org/10.5944/epos.35.2019.25590

Montaner-Villalba, S. (2019) Competencia en producción escrita en inglés para fines específicos mediante el Blogging en un entorno de Aprendizaje Basado en Proyectos, Revista de Lenguas para fines específicos, 25(2), 173-192. DOI: http://dx.doi.org/ $10.20420 /$ rlfe.2019.292

NDT Resource Center (2021). Retrieved 16 March 2021, from https://www.cnde.iastate. edu/nde-education/ndt-resource-center/

Norberg, A., Dziuban, C., Moskal, P. (2011) A Time Based Blended Learning Model. On the Horizon, 19(3): 207-216http://dx.doi.org/10.1108/10748121111163913.

O'flaherty, J.; Phillips, C. (2015): «The use of flipped classrooms in higher education: A scoping review», The Internet and Higher Education, 25, 85-95.

Perdomo, W. (2016): «Estudio de evidencias de aprendizaje significativo en un aula bajo el modelo flipped classroom», EDUTEC, Revista Electrónica de Tecnología Educativa, 55, 1-17. http://www.edutec.es/revista/index.php/edutec-e/article/view/ 618/Edutec_n55_Perdomo

Roach, T. (2014): «Student perceptions toward flipped learning: New methods to increase interaction and active learning in economics», International Review of Economics Education, 17, 74-84.

Santiago Benítez, Gisela, Caballero Álvarez, Rebeca, Gómez Mayén, Diana, and Domínguez Cuevas, Atenea (2013). El uso didáctico de las TIC en escuelas de educación básica en México. Revista Latinoamericana de Estudios Educativos (México), XLIII(3),99-131.[fecha de Consulta 16 de Marzo de 2021]. ISSN: 01851284. Retrieved from: https://www.redalyc.org/articulo.oa?id=270/27028898004

Sauro, S., and Sundmark, B. (2019). Critically examining the use of blog-based fan fiction in the advanced language classroom. ReCALL, 31(1), 40-55. doi:10.1017/ S0958344018000071

Saverv, J. (2006). Overview of problem-based learning: Definitions and distinctions. Interdisciplinarv Journal of Problem-Based Learning, 1(1), 9-20.

Sife, A., Lwoga, E. and Sanga, C. (2007). New technologies for teaching and learning: Challenges for higher learning institutions in developing countries. International Journal of Education and Development using ICT, 3(2), 57-67. Open Campus, The University of the West Indies, West Indies. Retrieved March 15, 2021 from https://www.learntechlib.org/p/42360/.

Sitzmann, T., Kraiger, K., Stewart, D., and Wisher, R. A. (2006). The comparative effectiveness of web-based and classroom instruction: A meta-analysis. Personnel Psychology, 59,623-664.

Thomas, J.W., Mergendoler,J.R., and A.Michaelson (1999).Project-BasedLearning: A Handbok for Midleand High School Teachers. Buck Institute for Education. (htp:/w.bie.org) 
Vega, F., E. Portillo, M. Cano and B. Navarrete (2014), Experiencias de aprendizaje en la ingeniería química: diseño, montaje y puesta en marcha de una unidad de destilación a escala de laboratorio mediante el aprendizaje basado en problemas, Form. Univ, 7(1), 13-22

Vizcarro, C.,and E. Juárez (2008), ¿Qué es y cómo funciona el aprendizaje basado en problemas?, in El aprendizaje basado en problemas en la enseñanza universitaria, by Universidad de Murcia, Servicio de Publicaciones, pp. 17-36 Murcia, España

Walvoord BE, and Anderson VJ (1998). Effective grading: A tool for learning and assessment. San Francisco: Jossey-Bass.

Whiteside, A. L., Dikkers, A. G., y Lewis, S. (2016). More Confident Going into College: Lessons Learned from Multiple Stakeholders in a New Blended Learning Initiative. Online Learning, 20(4), 136- 156.

Zhao, Yong; Lei, Jing; Yan, Bo; Lai, Chun; Tan, Hueyshan Sophia, Teachers College Record, v107 n8 p1836-1884 Aug 2005. 